\title{
Analisis Implementasi Kebijakan Harga Transfer Pada CV ABC Yogyakarta
}

\section{Tatik}

Fakultas Ekonomi, Universitas Islam Indonesia, Yogyakarta

\begin{abstract}
This study aims to analyze the implementation of transfer pricing policies on $C V$ ABC Yogyakarta. This research uses a qualitative approach with a case study method. The data used are primary data sourced from direct observation, and documentation of financial records. The results showed the transfer price set by the company using the market price method. Market prices are considered an appropriate method of determining transfer prices because products transferred between divisions are in the external market as well. However, in the calculation of the contribution margin of the Division that transfers the product it needs to be reevaluated. Overheads have not yet been calculated in calculating the contribution margin.
\end{abstract}

Keywords: Transfer Prices, Policy Implementation, Market Price Methods

\section{Pendahuluan}

Pesatnya kemajuan era digital memberikan kemudahan bagi semua pihak untuk mengakses informasi. Menurut hasil survey Asosiasi Penyelenggara Jasa Internet Indonesia (APJII) tahun 2016, ada 132.700.000 pengguna internet di Indonesia dari jumlah populasi 256.200 .000 orang atau sebesar $51,8 \%$. Itu berarti lebih dari separuh penduduk Indonesia telah tersambung dengan internet. (Fahmi, 2017).

Kemudahan akses informasi dengan jaringan internet tersebut membuka peluang besar bagi pelaku bisnis di Indonesia. Promosi melalui media online dapat dioptimalkan ke seluruh wilayah. Melalui promosi yang optimal, diharapkan penjualan meningkat dan berpengaruh juga terhadap peningkatan laba perusahaan.

Namun, pelaku bisnis juga mengalami tantangan baru dengan persaingan bisnis yang semakin ketat. Dengan kemudahan akses informasi, konsumen dapat membandingkan berb agai produk dari puluhan bahkan ratusan produsen. Pelaku 
bisnis harus memiliki keunggulan untuk memenangkan persaingan sehingga konsumen memilih produk maupun jasa yang ditawarkan.

Salah satu informasi yang sering dibandingkan oleh konsumen melalui media promosi online adalah harga jual suatu produk atau jasa. Jika suatu produk atau jasa memiliki spesifikasi dan kualitas yang hampir sama, tentu konsumen akan memilih produsen yang memberikan harga lebih murah.

Bagi perusahaan yang menerapkan sistem autonomi divisi dan terjadi jual beli antar divisi, sangat penting memperhatikan penentuan harga transfer antar divisi yang bersangkutan. Karena penentuan harga transfer tidak hanya terkait dengan penilaian kinerja suatu divisi, melainkan juga berpengaruh terhadap penentuan harga jual produk. Harga jual yang tidak kompetitif dapat mengakibatkan perusahaan kalah bersaing di pasar.

Harga transfer adalah harga produk atau jasa yang ditransfer secara internal antarpusat pertanggungjawaban dalam sebuah perusahaan. Pusat pertanggungjawaban dalam sebuah perusahaan dapat disebut sebagai sebuah divisi. Divisi yang membeli produk dari divisi lain disebut divisi pembeli, sedangkan divisi yang menjual produk ke divisi lain disebut divisi penjual. (Slamet Sugiri Sodikin, 2015).

Manajemen pusat pada perusahaan yang menjaga otonomi divisi tidak akan menentukan nominal harga transfer melainkan memberikan beberapa kebijakan untuk mengatur penentuan harga transfer. Kebijakan tersebut bertujuan untuk mencapai laba perusahaan sebagai satu kesatuan usaha, sehingga diharapkan divisi penjual dan divisi pembeli dapat bersepakat dengan harga transfer yang ditentukan.

CV ABC merupakan sebuah perusahaan yang bergerak dalam bidang digital dan berlokasi di Yogyakarta. CV ABC melakukan pemasaran online dan telah memiliki pelanggan dari wilayah Yogyakarta, Jawa, Sulawesi dan Kalimantan. Perusahaan ini memiliki dua divisi, yaitu Divisi Mitra yang bertugas membuat produk dan Divisi Smart yang bertugas menjual produk. Divisi Smart membeli produk yang dijual oleh Divisi Mitra dan terjadi penentuan harga transfer antar kedua divisi tersebut.

Dari uraian diatas menjadi dasar peneliti untuk mengambil judul penelitian 
“Analisis Implementasi Kebijakan Harga Transfer Pada CV ABC Yogyakarta”.

\section{Rumusan Masalah}

Berdasarkan uraian latar belakang di atas, maka peneliti merumuskan permasalahan penelitian sebagai berikut:

1. Bagaimanakah kebijakan penentuan harga transfer pada Divisi Mitra dan Divisi Smart di CV ABC Yogyakarta?

2. Apakah harga transfer yang ditetapkan telah wajar bagi Divisi Mitra dan Divisi Smart dan mampu memberikan margin kontribusi yang diharapkan masingmasing divisi?

\section{Tinjauan Pustaka}

\subsection{Pengertian Harga Transfer}

Menurut Slamet Sugiri Sodikin (2015) harga transfer adalah harga produk atau jasa yang ditransfer secara internal antarpusat pertanggungjawaban dalam sebuah perusahaan. Pendapat Slamet Sugiri juga diperkuat oleh Ninik Anggraini (2012) yang mengemukakan bahwa harga transfer pada dasarnya adalah harga produk atau jasa yang dipertukarkan (diperjualbelikan) antara pusat pertanggungjawaban didalam suatu organisasi.

\subsection{Metode Harga Transfer}

Pada umumnya, harga transfer yang ditentukan telah memperhitungkan laba bagi divisi penjual. Meskipun pihak yang membeli produk merupakan divisi lain dalam satu perusahaan, divisi penjual juga memiliki target laba seperti wajarnya saat produk tersebut dijual ke pasar eksternal.

Pertimbangan masing-masing divisi, baik divisi penjual maupun divisi pembeli, berpengaruh terhadap laba perusahaan sebagai kesatuan. Selain itu, jika divisi pembeli yang akan menentukan harga jual produk ke konsumen akhir, harga transfer secara tidak langsung juga akan memperngaruhi persaingan perusahaan dalam pasar eksternal.

Para pakar akuntansi manajemen menyebutkan ada beberapa metode dalam penentuan harga transfer, yaitu harga transfer berbasis pasar (market based transfer price), harga transfer negosiasian (negotiated transfer price) dan harga transfer berbasis biaya (cost based transfer price). 
a. Harga transfer berbasis pasar (market based transfer price)

Harga pasar adalah harga produk (barang dan jasa) yang terjadi di pasar eksternal sebagai hasil akhir dari proses tawar menawar seluruh pelaku pasar (produsen dan konsumen). Jika pasar tersebut adalah pasar persaingan sempurna, maka harga pasar tersebut tepat dijadikan harga transfer.

Metode harga pasar merupakan pendekatan yang paling banyak digunakan dalam penetapan harga transfer. Dalam metode ini diasumsikan bahwa semua produk yang dibuat oleh divisi penjual dapat diserap juga oleh pasar sehingga divisi penjual bekerja pada kapasitas penuh (Krismiaji, Y Anni Aryani 2011).

Harga pasar akan menjadi ideal digunakan menjadi harga transfer jika terdapat kondisi:

1. Produk yang ditransfer diperjual belikan di pasar eksternal

2. Pasar eksternal merupakan pasar persaingan sempurna

3. Divisi pembeli bebas membeli produk sebanyak apapun dari sumber manapun, baik dari pasar internal (divisi penjual dalam satu perusahaan yang sama) maupun dari pasar eksternal.

4. Divisi penjual bebas menjual produk ke pasar manapun, baik ke pasar internal maupun ke pasar eksternal.

b. Harga transfer negosiasian (negotiated transfer price)

Harga transfer negosiasian digunakan jika tidak terdapat pasar persaingan sempurna. Dalam kenyataannya, memang pasar persaingan sempurna hampir tidak pernah terjadi. Misalnya ada produsen yang menjual produk dengan kuantitas yang sangat besar sehingga menurunkan harga pasar. Ketidaksempurnaan pasar mengakibatkan harga pasar tidak cocok untuk menentukan harga transfer.

Kedua divisi perlu bernegosiasi untuk menentukan harga transfer. Negosiasi harus mempertimbangkan biaya kesempatan yang dihadapi divisi penjual maupun divisi pembeli.

Menurut Slamet Sugiri (2015) terdapat kelemahan jika menggunakan harga transfer negosiasian adalah: 
1. Jika manager divisi tertentu memiliki informasi yang lebih lengkap dibandingkan manager divisi lain, manager divisi tersebut dapat mengambil manfaat dari manager lain sehingga manager lain dirugikan.

2. Ukuran kinerja manager dapat tersamarkan oleh kemampuan negosiasi manager tertentu.

3. Proses negosiasi membutuhkan banyak waktu, tenaga dan beban.

4. Jika tidak terjadi kesepakatan antar manager, manager pusat perlu melakukan intervensi, bahkan memerlukan arbitrator untuk proses arbitrase dalam kondisi tertentu.

Namun, meskipun terdapat beberapa kelemahan dalam metode harga transfer berdasarkan negosiasian, metode ini juga memiliki kelebihan yaitu evaluasi prestasi divisi akurat, keselerasan tujuan antara divisi dan perusahaan serta autonomi divisi tetap terjaga.

c. Harga transfer berbasis biaya (cost based transfer price)

Metode harga transfer berbasis biaya digunakan jika tidak terdapat pasar persaingan sempurna dan harga transfer negosiasian tidak dapat ditentukan. Biaya yang menjadi dasar adalah biaya standar, bukan biaya historis ataupun biaya yang sesungguhnya terjadi untuk memproduksi produk yang ditransfer.

Biaya standar yang dipakai sebagai dasar penentuan harga transfer dapat dihitung dengan salah satu dari tiga pendekatan yaitu biaya produksi variabel, biaya produksi penuh atau biaya produksi plus laba.

Biaya produksi variabel merupakan biaya produksi yang sifatnya variabel saja. Kelemahan dengan menggunakan dasar biaya produksi variabel, divisi penjual akan mencatat margin kontribusi nol sehingga merugikan divisi penjual jika perusahaan menilai kinerja divisi sebagai pusat pertanggungjawaban laba.

Biaya produksi penuh terdiri dari biaya produksi variabel dan biaya produksi tetap. Sama halnya dengan dasar biaya produksi variabel, jika perusahaan menilai kinerja divisi sebagai pusat pertanggungjawaban laba, metode ini juga mempunyai kelemahan, yaitu divisi penjual akan melaporkan laba nol karena harga transfer sesuai dengan biaya produksi penuh.

Jika perusahaan menilai kinerja divisi sebagai pusat pertanggungjawaban 
laba, harga transfer yang layak digunakan adalah biaya produksi plus laba. Hal yang perlu diperhitungkan dengan menggunakan biaya produksi plus laba ini ada dua. Pertama, penentuan dasar perhiutngan untuk menetapkan tingkat laba. Kedua, penentuan tingkat labanya.

\section{Metode Penelitian}

Metode penelitian merupakan cara utama yang digunakan peneliti untuk mencapai tujuan dan menentukan jawaban atas masalah yang diajukan. Sugiyono (2014) berpendapat bahwa metode penelitian merupakan cara ilmiah untuk mendapatkan data dengan tujuan dan kegunaan tertentu.

Ada beberapa metode dalam penelitian kualitatif yaitu eksperimen, survei, historis, analisis informasi dokumenter dan studi kasus.

Tabel III.1 Perbedaan Metode Penelitian

\begin{tabular}{|l|l|l|l|}
\hline \multicolumn{1}{|c|}{ Strategi } & \multicolumn{1}{|c|}{ Bentuk Pertanyaan } & $\begin{array}{c}\text { Kontrol terhadap } \\
\text { peristiwa perilaku }\end{array}$ & \multicolumn{1}{|c|}{$\begin{array}{c}\text { Fokus terhadap } \\
\text { peristiwa kontemporer }\end{array}$} \\
\hline Eksperimen & Bagaimana, mengapa & Ya & Ya \\
\hline Survei & $\begin{array}{l}\text { Siapa, apa, dimana, } \\
\text { berapa banyak }\end{array}$ & Tidak & Ya \\
\hline Analisis Arsip & $\begin{array}{l}\text { Siapa, apa, dimana, } \\
\text { berapa banyak }\end{array}$ & Tidak & Ya/Tidak \\
\hline Historis & Bagaimana, mengapa & Tidak & Tidak \\
\hline Studi Kasus & Bagaimana, mengapa & Tidak & Ya \\
\hline
\end{tabular}

Sumber: K Yin, 2012

Mempertimbangkan faktor-faktor di atas, penulis memilih pendekatan kualitatif dengan metode studi kasus. Dalam penelitian dengan pendekatan kualitatif ini menghasilkan data deskriptif; ucapan atau tulisan dan perilaku yang diamati dari orang-orang (subyek) itu sendiri.

\section{Spesifikasi Penelitian}

Spesifikasi penelitian ini bersifat deskriptif, karena penelitian ini merupakan suatu upaya untuk mendiskripsikan harga transfer yang diterapkan oleh CV ABC Yogyakarta. Hal tersebut dilakukan dengan cara mengungkapkan dan memaparkan penerapan kebijakan dan metode harga transfer antara divisi terkait. Selanjutnya, hasil evaluasi tersebut dibahas dan dianalisa sehingga dapat diambil kesimpulan.

\section{Data dan Tehnik Pengumpulan Data}

Data untuk studi kasus bisa berasal dari enam sumber yaitu: dokumen, rekaman arsip, wawancara, pengamatan langsung, observasi partisipan dan 
perangkat-perangkat fisik. Pada penelitian studi kasus, data yang disebutkan dalam proposal penelitian dapat berkembang seiring berjalannya penelitian.

Sumber data yang digunakan pada penelitian ini adalah dokumen keuangan dan wawancara kepada pihak terkait untuk memperoleh informasi yang lebih lengkap dan akurat terkait dokumen tersebut.

\section{Analisis Data}

Analisis data kualitatif adalah upaya yang dilakukan dengan jalan bekerja dengan data, mengorganisasikan data, memilah-milahnya menjadi satuan yang dapat dikelola, mensintesiskannya, mancari dan menemukan pola, menemukan apa yang penting dan apa yang dipelajari, dan memutuskan apa yang dapat diceritakan kepada orang lain. Analisis data dilakukan sepanjang penelitian dan dilakukan secara terus menerus dari awal sampai akhir penelitian.

Proses penelitian ini berbentuk siklus meliputi pengumpulan data, display data, reduksi data, dan penarikan kesimpulan.

\section{Hasıl Dan Pembahasan}

\section{Profil CV ABC Yogyakarta}

CV ABC merupakan salah satu entitas bisnis yang merupakan Usaha Mikro Kecil dan Menengah (UMKM) yang diresmikan tahun 2016 di Sleman Yogyakarta. Pada awalnya, CV ABC merupakan usaha perorangan yang fokus menjual jadwal sholat digital. Perusahaan tersebut kemudian memutuskan untuk memproduksi sendiri jadwal sholat digital serta memperluas unit bisnisnya dengan melayani kebutuhan masjid lainnya, seperti kubah, karpet masjid dan perawatan karpet masjid. Seiring perkembangan perusahaan, CV ABC juga membuka cabang di kota Kudus, Malang dan Klaten.

Di dalam CV ABC terdapat tiga divisi sebagai pusat pertanggungjawaban, yaitu Divisi Mitra, Divisi Smart dan Divisi Insan Masjid. Divisi Mitra memproduksi barang yang ditransfer ke Divisi Smart dan Divisi Smart menjual produk ke end user. Sementara Divisi Insan Masjid tidak melakukan proses produksi karena produk yang dijual ke pasar merupakan barang jadi yang sebagian besar merupakan produk import, dan produk atau jasa yang dijual tidak terkait dengan Divisi Mitra dan Divisi Smart. 


\section{Hasil Penelitian dan Analisis Data}

\section{Proses Bisnis}

Proses bisnis di CV ABC yang melibatkan Divisi Mitra dan Divisi Smart dapat diuraikan sebagai berikut:

1. Konsumen melakukan pemesanan jadwal sholat digital ke Customer Service Divisi Smart. Pemesanan akan diproses jika konsumen telah melakukan pembayaran down payment (uang muka pesanan) minimal 50\% dari harga barang.

2. Divisi Smart mengisi form order barang dan menyerahkan ke Divisi Mitra.

3. Divisi Mitra melakukan pemrograman jadwal sholat berdasarkan dengan form order dari Divisi Smart. Program jadwal sholat disesuaikan dengan wilayah konsumen. Konsumen juga dapat memesan tambahan fitur produk yang akan disetting secara digital atau otomatis, misalnya tilawah 1 juz setiap hari di waktu tertentu, dzikir al ma'tsurot setiap hari di pagi dan petang, penghitung waktu jeda adzan dan iqomat, dan lain sebagainya.

4. Proses finishing di Divisi Mitra dilakukan dengan memberikan back ground jadwal sholat digital berdasarkan form order pada barang setengah jadi yang telah dirakit. Back ground biasanya mencatumkan nama masjid, alamat masjid, foto masjid yang bersangkutan atau foto masjid yang diinginkan (misalnya masjid Nabawi, masjid Al Aqsho, dan lain-lain) dan institusi donator (jika diperlukan).

5. Barang jadi berupa jadwal sholat digital dari Divisi Mitra ditransfer ke Divisi Smart setelah melewati Fungsi Quality Control.

6. Divisi Smart memberikan konfirmasi kepada konsumen bahwa barang pesanan telah selesai dikerjakan dan melakukan penagihan pelunasan.

7. Barang jadi akan dikirimkan oleh Divisi Smart jika konsumen telah melakukan pelunasan pembayaran. Konsumen dapat meminta layanan pemasangan barang jadi (jadwal sholat digital) dan memberikan tambahan biaya atas jasa pemasangan tersebut.

\section{Harga Transfer Antar Divisi}

Divisi yang terkait dengan harga transfer adalah Divisi Mitra dan Divisi 
Smart. Secara garis besar Divisi Mitra bertugas melakukan produksi barang dan Divisi Smart bertugas melayani penjualan ke konsumen.

Harga transfer yang terjadi di dalam CV ABC, antara Divisi Mitra dan Divisi Smart sebagai berikut:

Tabel 4.1

Rekap Harga Transfer Divisi Mitra ke Divisi Smart CV ABC Tahun 2018

\begin{tabular}{clr}
\hline NO. & TIPE & \multicolumn{2}{c}{$\begin{array}{c}\text { HARGA TRANSFER } \\
\text { (Div. Mitra ke Div. Smart) }\end{array}$} \\
\hline 1 & Hanifah & 950.000 \\
2 & Mekkah & 1.300 .000 \\
3 & Madinah & 1.450 .000 \\
4 & Shofa & 1.650 .000 \\
5 & Marwa & 1.750 .000 \\
6 & Mina & 2.250 .000 \\
7 & Rihaal & 2.200 .000 \\
8 & Qiyada & 3.200 .000 \\
9 & Ziyada & 3.000 .000 \\
10 & Ottoman & 2.800 .000 \\
11 & Shofiya & 3.500 .000 \\
12 & Raudhoh & 1.400 .000 \\
13 & Mumtaz & 7.020 .000 \\
\hline
\end{tabular}

Harga transfer dari Divisi Mitra dijadikan harga pokok penjualan oleh Divisi Smart. Adapun harga jual produk ke end user atau konsumen yang ditetapkan oleh Divisi Smart sebagai berikut:

Tabel 4.2

List Harga Jual Jadwal Sholat Digital Divisi Smart CV ABC Tahun 2018

\begin{tabular}{clr}
\hline NO. & TIPE & dalam rupiah \\
\hline 1 & Hanifah & HARGA JUAL \\
2 & Mekkah & 1.400 .000 \\
3 & Madinah & 1.800 .000 \\
4 & Shofa & 2.250 .000 \\
5 & Marwa & 2.500 .000 \\
6 & Mina & 2.500 .000 \\
7 & Rihaal & 3.500 .000 \\
8 & Qiyada & 3.500 .000 \\
9 & Ziyada & 5.000 .000 \\
10 & Ottoman & 4.000 .000 \\
11 & Shofiya & 3.500 .000 \\
12 & Raudhoh & 5.000 .000 \\
13 & Mumtaz & 1.750 .000 \\
\hline
\end{tabular}




\section{Pembahasan}

Harga transfer yang terjadi antara Divisi Mitra dengan Divisi Smart dengan kebijakan perusahaan untuk masing-masing tipe yaitu Hanifah Rp 950.000, Mekkah Rp 1.300.000, Madinah Rp 1.450.000, Shofa Rp 1.650.000, Marwa Rp 1.750.000, Mina Rp 2.250.000, Rihaal Rp 2.200.000, Qiyada Rp 3.200.000, Ziyada Rp 3.000.000, Ottoman Rp 2.800.000, Shofiya Rp 3.500.000, Raudhoh Rp 1.400.000, dan Mumtaz Rp 7.020.000.

Harga transfer yang ditetapkan tersebut menggunakan metode harga pasar. Harga pasar adalah harga produk yang terjadi di pasar eksternal sebagai hasil akhir dari proses tawar menawar seluruh pelaku pasar (produsen dan konsumen). (Slamet Sogiri Sodikin, 2015).

Divisi Mitra mempertimbangkan harga transfer dengan bench mark harga jual dari produsen sejenis dari luar perusahaan. Hal ini dianggap cukup menguntungkan bagi Divisi Mitra, karena menurut perhitungan Divisi Mitra, harga transfer tersebut sudah memberikan margin kontribusi rerata $26 \%$.

Adapun rincian margin kontribusi per tipe menurut perhitungan Divisi Mitra adalah Hanifah 10\%, Mekkah 43\%, Madinah 19\%, Shofa 29\%, Marwa 10\%, Mina $28 \%$, Rihaal 43\%, Qiyada 30\%, Ziyada 22\%, Ottoman 43\%, Shofiya 11\%, Raudhoh $33 \%$, dan Mumtaz Rp 20\%.

Margin kontribusi tersebut diperoleh dari perhitungan selisih antara harga transfer ke Divisi Smart dan harga pokok penjualan. Namun dalam perhitungan harga pokok penjualan, Divisi Mitra tidak memasukkan unsur biaya overhead. Untuk Divisi Mitra seharusnya ada biaya overhead variabel yang perlu diperhitungkan yaitu biaya penyusutan mesin dan peralatan produksi, bahan habis pakai, biaya listrik dan biaya mandor (koordinator) produski. Manajemen seharusnya melakukan review atas perhitungan harga pokok penjualan tersebut sebagai dasar evaluasi harga transfer antra divisi.

Harga transfer dengan metode harga pasar ditetapkan perusahaan agar kedua divisi tetap memperoleh keuntungan dan bisa bersaing di pasar eksternal. Meskipun pada kenyataannya, Divisi Mitra tidak bisa menjual produknya ke pasar eksternal 
karena seluruh penjualan produk harus melalui Divisi Smart.

Sedangkan Divisi Smart bisa membeli produk dari pasar eksternal dengan harga yang sama, namun masih memerlukan tambahan biaya ongkos kirim. Pembelian ke produsen lain di luar perusahaan juga membutuhkan waktu pemesanan yang lebih lama dibandingkan membeli produk dari Divisi Mitra.

Selain itu, jika terjadi kerusakan pada produk, proses service tidak dapat dilakukan segera karena harus produk harus dibawa ke produsen dan mengantri untuk dilakukan perbaikan. Kemudian produk yang telah diperbaiki baru dikirimkan kembali ke Divisi Smart. Hal ini tentu mempengaruhi kepuasan konsumen terhadap kecepatan waktu penyelesaian pesanan dan service produk.

Menurut Divisi Smart, harga transfer dari Divisi Mitra juga menguntungkan karena mampu memberikan kontribusi margin rerata 32\%. Manajemen menetapkan kebijakan kontribusi margin minimal 30\%.

Berikut ini disajikan rincian margin kontribusi menurut perhitungan Divisi Smart:

Tabel 4.3

Margin Kontribusi Tiap Tipe - Divisi Smart CV ABC

Tahun 2018

\begin{tabular}{llrrrr}
\hline NO. & TIPE & $\begin{array}{l}\text { HARGA } \\
\text { POKOK } \\
\text { PENJUALAN }\end{array}$ & \multicolumn{1}{l}{$\begin{array}{l}\text { HARGA } \\
\text { JUAL }\end{array}$} & \multicolumn{2}{l}{$\begin{array}{l}\text { MARGIN } \\
\text { KONTRIBUSI } \\
\text { (Rupiah) }\end{array}$} \\
\hline 1 & Hanifah & 950.000 & 1.400 .000 & 450.000 & \multicolumn{1}{c}{$\%$} \\
2 & Mekkah & 1.300 .000 & 1.800 .000 & 500.000 & $28 \%$ \\
3 & Madinah & 1.450 .000 & 2.250 .000 & 800.000 & $36 \%$ \\
4 & Shofa & 1.650 .000 & 2.500 .000 & 1.850 .000 & $74 \%$ \\
5 & Marwa & 1.750 .000 & 2.500 .000 & 750.000 & $30 \%$ \\
6 & Mina & 2.250 .000 & 3.500 .000 & 1.250 .000 & $36 \%$ \\
7 & Rihaal & 2.200 .000 & 3.500 .000 & 1.300 .00 & $37 \%$ \\
8 & Qiyada & 3.200 .000 & 5.000 .000 & 1.800 .000 & $36 \%$ \\
9 & Ziyada & 3.000 .000 & 4.000 .000 & 1.000 .000 & $25 \%$ \\
10 & Ottoman & 2.800 .000 & 3.500 .000 & 700.000 & $20 \%$ \\
11 & Shofiya & 3.500 .000 & 5.000 .000 & 1.500 .000 & $30 \%$ \\
12 & Raudhoh & 1.400 .000 & 1.750 .000 & 350.000 & $20 \%$ \\
13 & Mumtaz & 7.020 .000 & 8.000 .000 & 980.000 & $13 \%$ \\
\hline
\end{tabular}

Dalam Divisi Smart harga pokok penjualan memang tidak ada penambahan biaya administrai variabel, biaya penjualan variabel maupun biaya variabel lainnya. Divisi ini menggunakan system jus in time, yaitu melakukan pemesanan ke Divisi 
Mitra jika telah mendapatkan pesanan dari konsumen.

Sementara untuk Divisi Mitra masih memperhitungkan safety stok, yaitu persediaan minimal yang dimaksudkan untuk mengantisipasi kekurangan barang atau ada keterlambatan bahan yang dipesan sampai di perusahaan.

\section{Kesimpulan}

Berdasarkan hasil dan pembahasan yang telah disusun oleh peneliti, peneliti menyimpulkan bahwa:

1. Harga transfer antara Divisi Mitra dan Divisi Smart di CV ABC ditetapkan dengan menggunakan metode harga pasar. Harga pasar diperoleh dari bench mark harga jual produk dari perusahaan sejenis.

2. Divisi Mitra mempertimbangkan harga transfer dengan bench mark harga jual dari produsen sejenis dari luar perusahaan. Hal ini dianggap cukup menguntungkan bagi Divisi Mitra, karena menurut perhitungan Divisi Mitra, harga transfer tersebut sudah memberikan margin kontribusi rerata $26 \%$. Namun posisi Divisi Mitra cukup lemah, karena masih terbatas menjual produk ke Divisi Smart, tidak ke pasar eksternal.

3. Perhitungan harga pokok penjualan pada Divisi Mitra tidak memasukkan unsur biaya overhead yaitu biaya penyusutan mesin dan peralatan produksi, bahan habis pakai, biaya listrik dan biaya mandor (koordinator) produksi.

4. Harga transfer dari Divisi Mitra dianggap menguntungkan bagi Divisi Smart karena dapat memberikan margin kontribusi sebesar 32\%, melebihi target yang ditetapkan perusahaan sebesar $30 \%$.

5. Divisi Smart menggunakan system just in time, yaitu melakukan pemesanan ke Divisi Mitra jika telah mendapatkan pesanan dari konsumen sehingga stok persediaan di Divisi ini. Sementara Divisi Mitra masih memperhitungkan safety stok untuk mengantisipasi kekurangan barang jika ada pesanan.

Adapun saran yang direkomendasikan peneliti berdasarkan analisis dalam pembahasan sebagai berikut:

1. Divisi Mitra sebaiknya memasukkan unsur biaya overhead yaitu biaya penyusutan mesin dan peralatan produksi, bahan habis pakai, biaya listrik dan 
biaya mandor (koordinator) produksi dalam perhitungan harga pokok penjualan sebagai dasar penetapan harga transfer.

2. Divisi Smart dapat memprioritaskan penjualan pada produk yang memberikan margin kontribusi tinggi sehingga berdampak pada peningkatan keuntungan divisi maupun perusahaan.

\section{DAFTAR PUSTAKA}

Abdul, Halim. 2013. Sistem Pengendalian Manajemen. Yogyakarta: UPP AMP YPKN.

Anthony, R. N., and Vijay Govindarajan. 2007. Management Control Systems. Edisi keduabelas. New York: McGraw-Hill Book Companies.

Aryo, Ibnu. 2010. Kebijakan Kewajiban Melampirkan Dokumen Penunjang Transfer Pricing di Indonesia (Analisis Perbandingan dengan Ketentuan Perpajakan di Cina dan India). Skripsi. Tidak Diterbitkan

Bambang Pamungkas dan Iriyadi. 2008. Pengukuran Kinerja dan Harga Transfer. Di:http//Researchgate.net

Baskoro, Ibnu Aryo. 2010. Kebijakan Kewajiban Melampirkan Dokumen Penunjang Transfer Pricing di Indonesia (Analisis Perbandingan dengan Ketentuan Perpajakan di Cina dan India). Skripsi.Tidak Diterbitkan.

Coach Dr. Fahmi, dkk. 2017. Strategi Anak Muda Bikin Bisnis UMKM Go Internasional. Intimedia.

Hansen, Mowen, 2009. Akuntansi Manajerial, Terjemahan Dewi Fitriasari dan Deny Arnor Kwary, 7th ed. Jakarta: Salemba Empat.

Krismiaji, Aryani Y. Anni. 2011. Akuntansi Manajemen. Edisi Kedua. Cetakan Pertama. UPP STIM YKPN. Yogyakarta

Miles, M.B, Huberman,A.M, dan Saldana,J. 2014. Qualitative Data Analysis, A Methods Sourcebook, Edition 3. USA: Sage Publications. Terjemahan Tjetjep Rohindi Rohidi, UI-Press.

Ninik Anggarini. 2012. Analisis Penentuan Harga Transfer Terhadap Kontribusi Laba Pada Pusat Pertanggungjawaban pada Perusahaan Rokok KN Jaya Sentosa Kediri. Jurnal Ilmiah Cendekia Akuntansi, 2018 - publikasi.uniska- 
kediri.ac.id

Sodikin, Slamet, Sugiri. 2015. Akuntansi Manajemen-Sebuah Pengantar. Edisi Kelima. Yogyakarta: UPP STIM YKPN.

Sugiyono. 2014. Metode Penelitian Kuantitatif, Kualitatif, dan R\&D. Bandung: Alfabeta.

Vidya, dkk. 2014. Penerapan Metode Full Costing dalam Penentuan Harga Transfer pada PT Massindo Sinar Pratama Manado. Jurnal EMBAVol 2. No.3. Universitas Sam Ratulangi

Yin, R. K. (2012). Studi Kasus, Desain \& Metodologi. Jakarta: Raja Grafindo Persada 